\title{
複合則理論を用いたコンクリートのヤング係数の推定式に関する研究 STUDY ON EQUATION FOR PREDICTING ELASTIC MODULUS OF CONCRETE BASED ON THE THEORY OF COMPOSITE MATERIAL
}

\author{
清原千鶴*, 永松静也**, 佐藤 嘉 昭***, 三橋博三**** \\ Chizuru. KIYOHARA, Seiki NAGAMATSU, Yoshiaki SATO \\ and Hirozo MIHASHI
}

\begin{abstract}
For high-strength and high-fluidity concrete, the water-cement ratio and the volume fraction of aggregate is lower than conventional concrete. In order to clarify systematically the deformation of these concrete, it is necessary to consider the effect of the volume of constituents in concrete. In this study, the estimation formula of modulus of elasticity of concrete was derived on the basis of a two-phase composite material model through experiments on the compressive strength and secant modulus of cement paste and concrete specimen with a same water-cement ratio respectively. The following conclusions may be drawn: 1) the relationships between cement-water ratio and modulus of elasticity of cement paste and concrete specimen were expressed by comparatively simple equations. 2) the elastic modulus of cement paste can be explained as a function of the cement-water ratio, and that of aggregate as a function of its absorption. 3) the proposed equation is able to estimate the compressive secant modulus of both normal and high strength concrete.
\end{abstract}

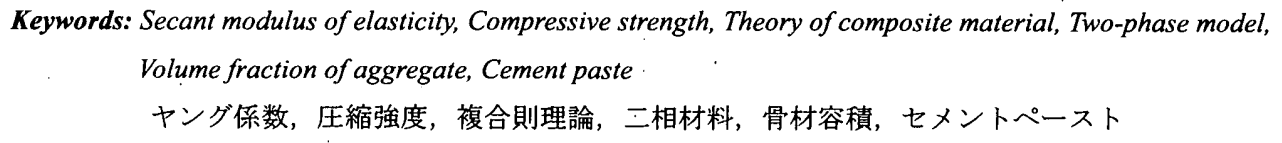

\section{1. はじめに}

本研究は, 多種多様にあるコンクリートのヤング係数をコンクリー トの調合設計時における水セメシ、比, 単位水量および骨材の物性を 要因として推定を行う方法を提案するものである。

コンクリートのヤング係数は, 構造設計時に部材の変形や剛性を評 価するための材料の特性として要求される基本的な因子であり，その 值が設計上の值と大きく異ならないよう配慮が必要となる。コンクリ 一ト構造物の性能規定や性能照査が要求される情勢のなか, コンクリ 一ト構造物の使用限界を検討する上においても, 調合設計時における コンクリートのヤング係数の正確な評価は意味があると考えられる。 コンクリートは, セメントペーストと細骨材および粗骨材を主成分 とする複合材料であり, ヤング係数は構成する物質の変形性状の和と して表されるため, 複合則理論が成立する。したがって, コンクリー トのヤング係数は, セメントペーストおよび骨材のヤング係数とそれ らの構成比の関数で表すことができる。これらの式は理論的に明確で あり,コンクリートの調合および構成物質の物性に関するデータを用 いることによって, コンクリートのヤング係数を算出することができ る。

コンクリートのヤング係数の推定方法としては, 大きく分けると複合則理
論を用いる方法と日本建築学会「鉄筋コンクリート構造計算規準・同解 説」にに示されているような数多くの実験結果に基づいて圧縮強度や単位 容積質量をパラメータとする推定式(式(1))を用いる方法がある。通常, 式の簡単さ, 奏用的価値の高さから, 式(1)に示されるような推定式が用 いられている。

$$
\begin{aligned}
& E=33.5 \times k 1 \times k 2 \times\left(\frac{\gamma}{2.4}\right)^{2} \times\left(\frac{F_{c}}{60}\right)^{\frac{1}{3}} \\
& \text { ここに, } E: \text { コンクリートのヤング係数 }\left(\mathrm{kN} / \mathrm{mm}^{2}\right) \\
& F_{c}: \text { コンクリートの設計基淮強度 }\left(\mathrm{N} / \mathrm{mm}^{2}\right) \\
& \gamma: \text { コンクリートの単位容積質量 }\left(\mathrm{t} / \mathrm{m}^{3}\right) \\
& k_{1}, k_{2}: \text { 骨材, 混和材による定数 }
\end{aligned}
$$

ここで, 過去10年間において日本国内で発表された圧縮強度とヤン グ係数の関係を調べてみると, 図-1に示すように骨材容積比(コンクリ 一トの容積に対する骨材の容積の比)は $0.45 \sim 0.75$ 範囲となっており， 同じ水セメント比でも骨材容積比には大きな差が見られる。また図-2 に示すように骨材容積比 $0.45 \sim 0.75$ の範囲でヤング係数が大きく変化 している。実験結果に基づいたヤング係数推定式では, コンクリート
* 大分大学工学部福祉環境工学科建築コース 助手. 工修 ** 北九州市立大学国際環境工学部環境空間デザイン学科 教授・工博

*** 大分大学工学部福祉環境工学科建築コース 教授・工博

**** 東北大学大学院工学研究科都市 $\cdot$ 建築学尃攻 教授・ 工博
Research Assoc., Dept. of Architecture Eng., Faculty of Eng., Oita Univ., M: Eng. Prof., Dept. of Environmental Space Design, Faculty of Environmental Eng., Kitakyushu Univ., Dr. Eng.

Prof., Dept. of Architecture Eng., Faculty of Eng., Oita Univ., Dr. Eng. Prof., Dept. of Architecture and Building Eng., Graduate School of Eng., Tohoku Univ., Dr. Eng. 


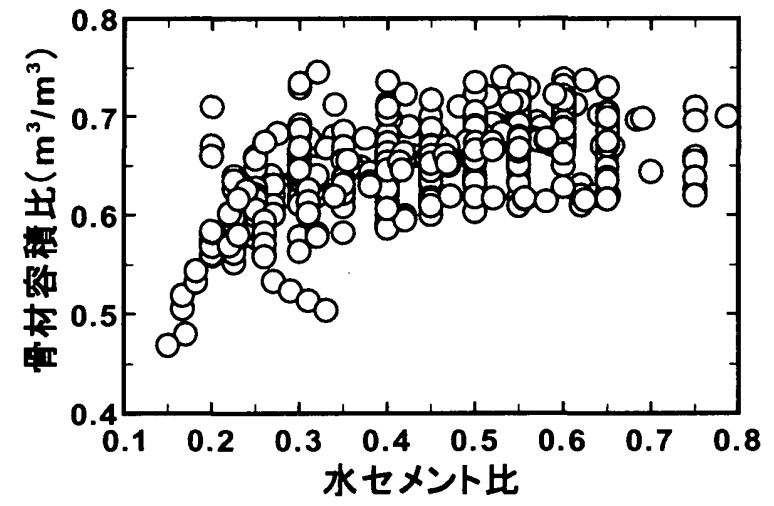

図-1 水セメント比と骨材容積比の関係

の単位容積質量 $(\gamma)$ の中に構成物質の量の影響が集約される形とな っている。しかし, 現在では, 普通コンクリートと比べて低水セメン 卜比, 高セメント量である高強度および高流動コンクリートを代表と する高機能，高性能コンクリートの開発が進められており，このよう な多種多様なコンクリートに対応するヤング係数推定式を構筑する ためには, 複合則理論に基づいて構成物質の変形性状とその構成量か ら推定する方がより沉用性が高いものと考えられる。また，川上の研 究 ${ }^{2} に$ 示されているように, 圧縮強度とヤング係数は異なる物理量で あるため, 複合材料としてのコンクリートのヤング係数を推定する場 合, 構成物質のヤング係数とその量に基づいて評価する方が理論的で ある。しかしながら，複合則理論に基づく推定方法は，複合モデルの 弾性理論解に基づいているため, 精密なモデルになるほどその式は複 雑となることに加えて, 構成材料の物性值が容易に得られないことな どによりコンクリートの工学的な取り扱いに適しておらず, 実用化さ れていないのが現状である。

本研究では, 複合則理論を用いた実用的なコンクリートのヤング 係数の推定式を確立することを最終目的としている。本論文は，その 最初のステップであり, 羰生条件およびセメントの種類を一定とした 条件下における普通コンクリート, 高強度コンクリートおよび軽量コ ンクリート I 種のヤング保数の推定式を提案することとし, 筆者らが これまでに行ってきたセメントペースト ${ }^{3)}$, 普通コンクリート ${ }^{4}$, 高強 度コンクリート5)および軽量コンクリート I 種()に関する実験結果を 基に，複合則理論を用いた推定式の適用性について検討を行った。

\section{2. 実験}

\section{1 実験概要}

本論文では, 細骨材および粗骨材ともに普通骨材を用いたコンクリ ートに関する実験 I, 実験 II, 粗骨材に軽量骨材を用いたコンクリー ト(軽量コンクリート I 種)に関する実験 IIIの3シリーズの実験につ いて検討を行った。これらの実験に使用した材料の物理的性質を表-1 に示す。また使用したコンクリートの調合を表-2に示す。軽量骨材は 流紋岩 (真珠岩の一種) 系ガラス質微粉末を主原料とした造粒型人工 軽量骨材である。表-1に示すように軽量骨材の吸水率は24時間で3.3\% と小さいことから，骨材のプレウェッチングは行わず，混練時に24 時間吸水分を練り混ぜ水に加えることとした。

実験 I では水セメント比を $0.25 \sim 0.65$ の 5 種類とし, 単位水量 $170 \mathrm{~kg} / \mathrm{m}^{3}$ を基準とした11調合とした。実験 IIでは，水セメント比を

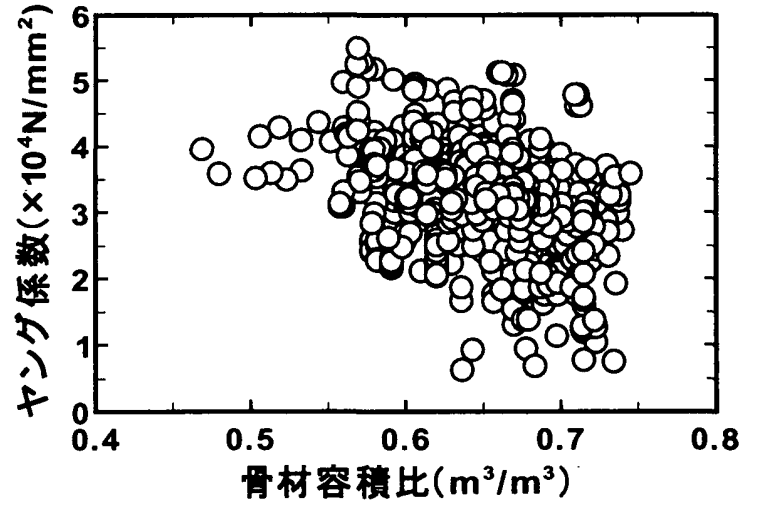

図-2 骨材容積比と水セメント比の関係

表-1 使用材料の物理的性質

\begin{tabular}{|c|c|c|}
\hline セメント & $\begin{array}{l}\text { 実験 } \\
\mathrm{I} \sim \mathrm{III}\end{array}$ & \begin{tabular}{|l} 
普通ポルトランドセメント \\
密度: $3.16 \mathrm{~g} / \mathrm{cm}^{3}$ \\
\end{tabular} \\
\hline \multirow{3}{*}{ 細骨材 } & 実験 I & $\begin{array}{l}\text { 松岡・蒲江産混合砂(海砂+山砂) } \\
\text { 密度: } 2.60 \mathrm{~g} \mathrm{~cm}^{3} \text {, 吸水率 }: 2.52 \% \text {, 粗粒率: } 2.62\end{array}$ \\
\hline & 実験 II & $\begin{array}{l}\text { 松岡·蒲江産混合砂 } \\
\text { 密度: } 2.60 \mathrm{~g} / \mathrm{cm}^{3} \text {, 吸水率: } 2.52 \% \text {, 粗粒率: } 2.62\end{array}$ \\
\hline & 実験 III & $\begin{array}{l}\text { 大分市片島産山砂 } \\
\text { 表乾密度: } 2.61 \mathrm{~g} / \mathrm{cm}^{3} \text {, 吸水率: } 1.68 \% \text {, 粗粒率: } 2.68 \\
\text { 長浜·平島産海砂 } \\
\text { 表乾密度: } 2.56 \mathrm{~g} / \mathrm{cm}^{3} \text {, 吸水率: } 1.74 \% \text {, 粗粒率 }: 2.66\end{array}$ \\
\hline \multirow{3}{*}{ 粗骨材 } & 実験 I & \begin{tabular}{|l} 
松岡産硬質砂岩砕石 \\
密度: $2.67 \mathrm{~g} / \mathrm{cm}^{3}$, 吸水率: $0.38 \%$, 粗粒率: 6.79
\end{tabular} \\
\hline & 実験 II & $\begin{array}{l}\text { 松岡産硬質砂岩砕石 } \\
\text { 密度: } 2.66 \mathrm{~g} / \mathrm{cm}^{3} \text {, 吸水率: } 1.24 \% \text {, 粗粒率: } 5.72\end{array}$ \\
\hline & 実験 III & $\begin{array}{l}\text { 造粒型人工軽量骨材 } \\
\text { (主原料: 流紋岩系ガラス質微粉末) } \\
\text { 表乾密度: } 0.92 \mathrm{~g} / \mathrm{cm}^{3}, 24 \mathrm{~h} \text { 吸水率: } 3.3 \% \text { (カタログ值) }\end{array}$ \\
\hline 混和凧 & $\begin{array}{l}\text { 実験 } \\
\mathrm{I} \sim \text { III }\end{array}$ & $\begin{array}{l}\text { 高性能 } \mathrm{AE} \text { 減水剤(ポリカルボン酸エーテル系) } \\
\text { ※実験 II は } \mathrm{AE} \text { 助剤も使用 }\end{array}$ \\
\hline
\end{tabular}

\section{表-2 調合表}

\begin{tabular}{|c|c|c|c|c|c|c|c|c|}
\hline \multirow{2}{*}{ 実験 } & \multirow{2}{*}{$\mathrm{W} / \mathrm{C}$} & \multirow{2}{*}{$\begin{array}{c}\text { s/a } \\
(\%)\end{array}$} & \multicolumn{4}{|c|}{ 单位質量 $\left(\mathrm{kg} / \mathrm{m}^{3}\right)$} & \multirow{2}{*}{$\begin{array}{c}\text { 高性能 } \mathrm{AE} \\
\text { 減水剂 } \\
(\mathrm{C} \times \%)\end{array}$} & \multirow{2}{*}{$\begin{array}{c}\mathrm{Va} \\
\left(\mathrm{m}^{3} / \mathrm{m}^{3}\right)\end{array}$} \\
\hline & & & $\mathrm{W}$ & $\mathrm{C}$ & $S$ & $\mathrm{G}$ & & \\
\hline \multirow{11}{*}{$\begin{array}{c}\text { 実験 } \\
\text { I }\end{array}$} & 0.25 & 36.6 & 170 & 680 & 536 & 950 & 1.30 & 0.570 \\
\hline & 0.35 & 39.1 & 170 & 486 & 635 & 1011 & 1.20 & 0.631 \\
\hline & \multirow{3}{*}{0.45} & 46.0 & 160 & 356 & 808 & 969 & 1.40 & 0.682 \\
\hline & & 44.6 & 170 & 378 & 762 & 970 & 1.10 & 0.665 \\
\hline & & 43.2 & 180 & 400 & 720 & 969 & 0.85 & 0.648 \\
\hline & \multirow{3}{*}{0.55} & 46.6 & 160 & 291 & 842 & 987 & 1.80 & 0.703 \\
\hline & & 46.4 & 170 & 309 & 820 & 969 & 1.20 & 0.687 \\
\hline & & 45.1 & 180 & 327 & 778 & 970 & 1.00 & 0.671 \\
\hline & \multirow{3}{*}{0.65} & 49.3 & 170 & 262 & 890 & 936 & 1.80 & 0.702 \\
\hline & & 47.3 & 175 & 269 & 844 & 964 & 1.65 & 0.695 \\
\hline & & 47.2 & 180 & 277 & 834 & 954 & 1.35 & 0.687 \\
\hline \multirow{12}{*}{$\begin{array}{c}\text { 実験 } \\
\text { II }\end{array}$} & \multirow{4}{*}{0.25} & 38.0 & 150 & 600 & 608 & 1014 & 1.76 & 0.615 \\
\hline & & 38.0 & 160 & 640 & 874 & 962 & 1.70 & 0.583 \\
\hline & & 38.0 & 170 & 680 & 552 & 926 & 1.70 & 0.560 \\
\hline & & 38.0 & 180 & 720 & 530 & 889 & 1.70 & 0.538 \\
\hline & \multirow{4}{*}{0.30} & 40.0 & 150 & 500 & 660 & 1017 & 1.80 & 0.636 \\
\hline & & 40.0 & 160 & 533 & 639 & 984 & 1.60 & 0.616 \\
\hline & & 40.0 & 170 & 567 & 618 & 952 & 1.50 & 0.596 \\
\hline & & 40.0 & 180 & 601 & 597 & 920 & 1.40 & 0.575 \\
\hline & \multirow{4}{*}{0.35} & 43.0 & 150 & 429 & 734 & 1000 & 1.80 & 0.658 \\
\hline & & 43.0 & 160 & 457 & 710 & 971 & 1.67 & 0.638 \\
\hline & & 43.0 & 170 & 486 & 692 & 943 & 1.50 & 0.621 \\
\hline & & 43.0 & 180 & 514 & 671 & 914 & 1.20 & 0.602 \\
\hline \multirow{4}{*}{$\begin{array}{c}\text { 実験 } \\
\text { III }\end{array}$} & 0.30 & 38.3 & 165 & 550 & \begin{tabular}{l|l|}
369 & 242 \\
\end{tabular} & 323 & 0.80 & 0.616 \\
\hline & 0.40 & 43.3 & 165 & 413 & \begin{tabular}{l|l}
447 & 293 \\
\end{tabular} & 318 & 0.80 & 0.659 \\
\hline & 0.50 & 46.7 & 170 & 340 & $4 9 5 \longdiv { 3 2 4 }$ & 307 & 0.90 & 0.677 \\
\hline & 0.60 & 47.5 & 175 & 292 & $512: 335$ & 307 & 1.20 & 0.688 \\
\hline
\end{tabular}

W/C : 水セメント比, s/a : 細骨材率, $\mathrm{w}:$ 水, $\mathrm{C}:$ セメント, $\mathrm{G}:$ 粗骨材, S : 細骨材, Va：骨材容積比 
$0.25,0.30,0.35$ の 3 種類とし, それぞれの水セメント比において単位 水量を150〜 $180 \mathrm{~kg} / \mathrm{m}^{3}$ の種類に変化させた 12 調合とした。実験 IIIでは 水セメント比を $0.30 \sim 0.60$ の種類とした。全てのコンクリートに使用 したセメントは普通ボルトランドセメントである。実験 I および実験 IIIでは目標スランプ $18 \pm 2 \mathrm{~cm}$ ，空気量 $4.5 \pm 1 \%$ を，実験 II では目標ス ランプ $20 \pm 2 \mathrm{~cm}$, 空気量 $3.5 \pm 1 \%$ を満足するように高性能AE減水剤で 調整を行った。

供試体はすべて材齢1日で脱型し，圧縮強度試験時まで恒温恒湿室 内(温度 $20 \pm 1{ }^{\circ} \mathrm{C}$, 相対湿度 $60 \pm 5 \%$ )にて封かん養生とした。圧縮強度 試験は $\phi 10 \times 20 \mathrm{~cm}$ の円柱供試体を用い, JIS A 1108 に準拠した。また， 圧縮強度試験時にコンプレッソメータにてひずみの測定を行い, 圧縮 忘力一ひずみ曲線を求め, JIS A 1149に準拠しヤング係数を算出した。

\section{2 実験結果}

表-3に材龄28日および1年の圧縮強度試験結果の一覧を示す。また, 図-3に材齡28日における圧縮強度とヤング係数の関係を示す。図中の 曲線は両者の関係を式(2)に示すようなべき乗関数で回帰した回帰曲 線である。

$$
E_{c}=a \cdot F_{c}^{b}
$$

$$
\text { ここに, } a, b: \text { 材料定数, } F_{c}: \text { 圧縮強度 }\left(\mathrm{N} / \mathrm{mm}^{2}\right)
$$

これによると,同一の圧縮強度で比較すると軽量コンクリートのヤ ング係数が小さいことが分かる。また，圧縮強度が増加する割合に対 してヤング係数が増加する割合が小さく，その傾向は高強度の範囲や 軽量コンクリートに顕著に見られる。

\section{3. 複合則理論式の適用}

コンクリートのヤング係数の推定フローを図-4に示す。複合則理論 の適用にあたって, コンクリートをモルタルと粗骨材, あるいはセメ ントペーストと骨材全体のどちらでモデル化するのが妥当かという 点については未だ結論は出ていない。本研究では, コンクリートを母 材セメントペーストと骨材の二相材料として取り扱うこととした。

B.Paul ${ }^{7}$ によれば，コンクリートに作用する応力が一様であるとき， またコンクリート中の各相に生じるひずみおよび応力が一様である とき, 二相系複合材料のヤング係数の上限值と下限值は並列式および 直列式で予測可能となる。しかしながらコンクリート中に発生する応 力やひずみのいずれも一様分布ではない。そこで，上限值および下限 值の中間の値を与える式が数多く提案されているが，本研究では， Hashin-Hansen式8)である式(3)を用いることとした。この式は，複合 モデルを幾何学モデルとし, 構成材料の相互作用から理論的に求めた Hashin式をHansenが構成材料のポアソン比を一定值 $(\mu a=\mu m=\mu c=$ 0.2)とし実用的な式にしたものである。

$$
\begin{aligned}
\frac{E_{c}}{E_{m}}= & \frac{\left(1-V_{a}\right) \cdot E_{m}+\left(1+V_{a}\right) \cdot E_{a}}{\left(1+V_{a}\right) \cdot E_{m}+\left(1-V_{a}\right) \cdot E_{a}} \\
こ こ に, & E_{c}, E_{m}, E_{a}: \\
& \text { コンクリート, 母材および骨材のヤング係数 }\left(\mathrm{N} / \mathrm{mm}^{2}\right) \\
& V_{a}: \text { 骨材容積比 }\left(\mathrm{m}^{3} / \mathrm{m}^{3}\right)
\end{aligned}
$$

\begin{tabular}{|c|c|c|c|c|c|c|}
\hline \multirow{2}{*}{ 実験 } & \multirow[b]{2}{*}{$\mathrm{W} / \mathrm{C}$} & \multirow{2}{*}{$\begin{array}{c}\text { 単位 } \\
\text { 水量 } \\
\left(\mathrm{kg} / \mathrm{m}^{3}\right)\end{array}$} & \multicolumn{2}{|c|}{ 材齢 28 日 } & \multicolumn{2}{|c|}{ 材龄 1 年 } \\
\hline & & & $\begin{array}{l}\begin{array}{l}\text { 縮強度 } \\
\left(\mathrm{N} / \mathrm{mm}^{2}\right)\end{array} \\
\end{array}$ & $\begin{array}{c}\text { ヤング係数 } \\
\left(\times 10^{4} \mathrm{~N} / \mathrm{mm}^{2}\right) \\
\end{array}$ & $\begin{array}{l}\text { 压縮強度 } \\
\left(\mathrm{N} / \mathrm{mm}^{2}\right) \\
\end{array}$ & $\begin{array}{c}\text { ヤング係数 } \\
\left(\times 10^{4} \mathrm{~N} / \mathrm{mm}^{2}\right) \\
\end{array}$ \\
\hline \multirow{11}{*}{$\begin{array}{c}\text { 実験 } \\
\text { I }\end{array}$} & 0.25 & 170 & 73.9 . & 3.63 & 83.8 & 4.19 \\
\hline & 0.35 & 170 & 55.2 & 3.33 & 65.9 & 3.94 \\
\hline & \multirow{3}{*}{0.45} & 160 & 34.2 & 2.88 & 45.7 & 3.34 \\
\hline & & 170 & 37.1 & 2.84 & 45.4 & 3.38 \\
\hline & & 180 & 39.9 & 2.89 & 54.0 & 3.43 \\
\hline & \multirow{3}{*}{0.55} & 160 & 29.3 & 2.66 & 36.1 & 2.96 \\
\hline & & 170 & 30.4 & 2.68 & 35.3 & 2.98 \\
\hline & & 180 & 32.4 & 2.75 & 37.5 & 3.16 \\
\hline & \multirow{3}{*}{0.65} & 170 & 22.7 & 2.38 & 27.8 & 2.76 \\
\hline & & 175 & 26.2 & 2.49 & 31.4 & 2.61 \\
\hline & & 180 & 25.6 & 2.49 & 31.0 & 2.78 \\
\hline \multirow{12}{*}{$\begin{array}{c}\text { 実験 } \\
\text { II }\end{array}$} & \multirow{4}{*}{0.25} & 150 & 73.2 & 3.47 & 81.5 & 3.75 \\
\hline & & 160 & 61.5 & 3.34 & 83.7 & 3.80 \\
\hline & & 170 & 72.0 & 3.26 & 85.7 & 3.84 \\
\hline & & 180 & 71.9 & 3.33 & 82.6 & 3.80 \\
\hline & \multirow{4}{*}{0.30} & 150 & 68.6 & 3.72 & 78.0 & 3.92 \\
\hline & & 160 & 64.7 & 3.44 & 75.4 & 3.83 \\
\hline & & 170 & 64.5 & 3.39 & 79.4 & 3.62 \\
\hline & & 180 & 61.2 & 3.28 & 74.8 & 3.71 \\
\hline & \multirow{4}{*}{0.35} & 150 & 48.8 & 3.42 & 67.9 & 3.78 \\
\hline & & 160 & 54.0 & 3.27 & 72.4 & 3.71 \\
\hline & & 170 & 413 & 3.29 & 65.0 & 3.51 \\
\hline & & 180 & 37.1 & 2.99 & 64.2 & 3.25 \\
\hline \multirow{4}{*}{$\begin{array}{c}\text { 実験 } \\
\text { III }\end{array}$} & 0.30 & 165 & 43.2 & 1.84 & 51.4 & 2.00 \\
\hline & 0.40 & 165 & 33.0 & 1.63 & 37.7 & 1.84 \\
\hline & 0.50 & 170 & 27.4 & 1.59 & 34.3 & 1.75 \\
\hline & 0.60 & 175 & 24.3 & 1.52 & 32.2 & 1.70 \\
\hline
\end{tabular}

本研究では, コンクリートを母材セメントペーストと骨材の二相材
表-3 圧縮強度試験結果

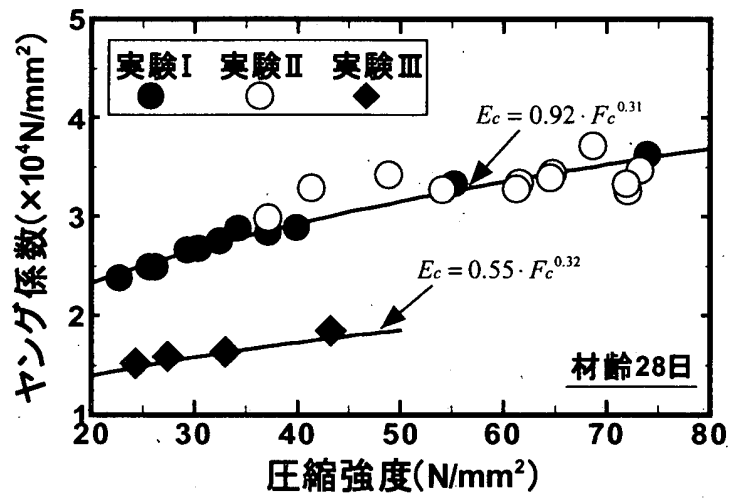

図-3 コンクリートの圧縮強度とヤング係数の関係 (材跉 28 日)

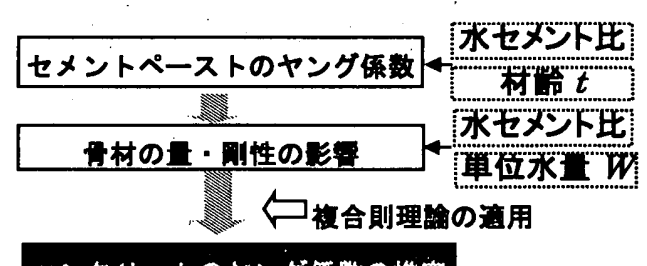

コンクリートのヤング保数の推定

図-4 複合則理論を用いたコンクリートの ヤング係数の推定フロー

料として取り扱うため，式(3)の母材のヤング係数Emはゼメントペー ストのヤング係数 $E_{p}$ と表すことにする。

複合則理論式(式(3))の適用にあたって，母材セメントペーストお よび骨材のヤング係数が必要になるが, 各構成材料のヤング係数は簡 単な式で表現できることが望ましい。ここでは, 各構成材料のヤング 
係数について以下のように推定を行った。

\section{1 セメントペーストのヤング係数 $\left(E_{p}\right)$ の推定}

コンクリート中のセメントペーストのヤング係数は直接測定する ことが出来ない。そこで, コンクリートと同じ水セメント比のセメン トペーストを単独に作製して得たヤング係数 ${ }^{3)}$ を利用することとした。 本研究ではコンクリート中の母材セメントペーストのヤング係数は, 単独で作製したヤング係数を基に，次のように仮定することとした。

$$
\begin{aligned}
& E_{p}(x, t)=k \cdot \bar{E}_{p}(x, t) \\
& \text { ここに, } E_{p}: \text { コンクリート中のセメントペーストのヤング係数 }
\end{aligned}
$$
$\left(\times 10^{4} \mathrm{~N} / \mathrm{mm}^{2}\right)$ $\bar{E}_{p}:$ 単独で作製したセメントペーストのヤング倸数 $\left(\times 10^{4} \mathrm{~N} / \mathrm{mm}^{2}\right)$

\section{$k:$ 補正保数}

$x:$ 水セメント比 (W/C), $t:$ 材齢 (日)

式(4)に示すように, 本研究では, コンクリート中の母材セメント ペーストは, 骨材界面に生じるマイクロクラックおよび骨材界面に形 成される遷移帯領域の影響を受けて, 見かけ上母材セメントペースト のヤング係数が低下すると考えて補正係数 $k$ を導入した。しかし，こ の補正係数kは, 水セメント比や測定材齢などの影響をうけ, 事前に 特定するのは困難である。そこで，ここでは，材㱓および水セメント 比をパラメータとして表すこととしたが, 補正係数の算出方法は後述 することにする。

水セメント比0.25 0.65のセメントペーストを作製し, 圧縮強度試 験を行い, ヤング係数を算出した。セメントペーストは, 混練後, ブ リーディング水がなくなり，打設可能となるフロー值 $200 \mathrm{~mm}$ 程度にな るまでの2, 3時間の間, 密封容器の中で定期的に摫拌し, その後型枠 に成型した。また, 全ての供試体はコンクリート供試体と同様に, 圧 縮強度試験時まで恒温恒湿室内にて封かん養生とした。

表-4に単独で作製したセメントペースト供試体を用いた圧縮強度 試験結果を示す。図-5に単独で作製したセメントペーストのヤング係 数Epの経時変化を示す。水セメント比によらず材齢 28 日までは急激 にヤング係数が上舁するが, その後值は一定値に収束する傾向を示し ている。本研究では式(5)に示すような水セメント比および試験材跉 をパラメータとする双曲線関数で回帰することとした。図中の曲線が 回帰曲線である。本実験と同様の一定条件下においては，式(4)およ び式(5)を用いることによって，任意の水セメント比および材齢のセ メントペーストのヤング係数が推定できることとなる。

$$
\begin{aligned}
& \bar{E}_{p}(x, t)=\frac{A \cdot t}{1+t} \quad A=0.036+0.66 \cdot \frac{1}{x} \\
& \text { ここに, } t: \text { 材齢 (日), } x: \text { 水セメント比 }
\end{aligned}
$$

\section{2 骨材のヤング係数 $\left(E_{a}\right)$ の推定}

骨材のヤング係数は, 試料を成型して測定することも可能ではある が, 多種多様にある骨材の弹性係数を直接求めることは容易ではない。 そこで，以下に示すようにそれぞれの骨材のヤング係数 $(E a)$ を間接 的に求めた。
表-4 セメントペーストの圧縮強度試験結果一覧

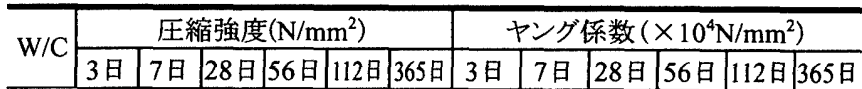
\begin{tabular}{l|l|l|l|l|l|l|l|l|l|l|l|l}
\hline 0.25 & 66.8 & 70.7 & 72.6 & 73.9 & 75.4 & 76.4 & 1.94 & 2.27 & 2.40 & 2.45 & 2.60 & 2.62 \\
\hline 0.35 & 55.5 & 62.1 & 64.6 & 65.6 & 65.3 & 65.8 & 1.60 & 1.73 & 1.90 & 2.01 & 2.12 & 2.13
\end{tabular} \begin{tabular}{l|l|l|l|l|l|l|l|l|l|l|l|l}
\hline 0.35 & 55.5 & 62.1 & 64.6 & 65.6 & 65.3 & 65.8 & 1.60 & 1.73 & 1.90 & 2.01 & 2.12 & 2.13 \\
\hline 0.45 & 38.5 & 49.0 & 54.4 & 55.0 & 56.3 & 56.4 & 1.09 & 1.22 & 1.52 & 1.56 & 1.55 & 1.61 \\
\hline
\end{tabular} \begin{tabular}{l|l|l|l|l|l|l|l|l|l|l|l|l}
\hline 0.45 & 38.5 & 49.0 & 54.4 & 55.0 & 56.3 & 56.4 & 1.09 & 1.22 & 1.52 & 1.56 & 1.55 & 1.61 \\
\hline 0.55 & 26.5 & 34.9 & 43.7 & 46.8 & 46.9 & 48.0 & 0.81 & 0.95 & 1.19 & 1.24 & 1.12 & 1.26
\end{tabular} \begin{tabular}{l|l|l|l|l|l|l|l|l|l|l|l|l}
0.55 & 26.5 & 34.9 & 43.7 & 46.8 & 46.9 & 48.0 & 0.81 & 0.95 & 1.19 & 1.24 & 1.12 & 1.26 \\
\hline 0.65 & 17.5 & 23.2 & 2.2 & 34.7 & 37. & 37.3 & 0.58 & 0.70 & 0.95 & 1.00 & 1.03 & 1.09
\end{tabular}

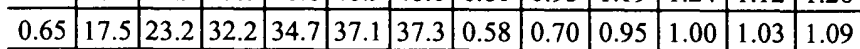

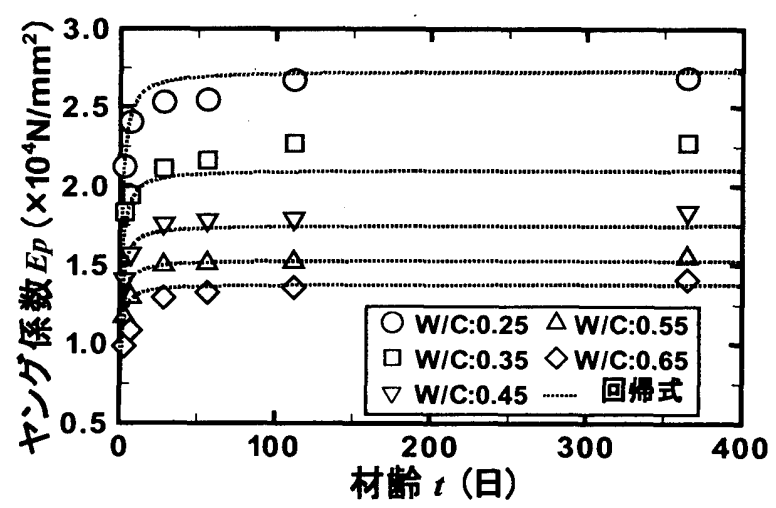

図-5 セメントペーストのヤング係数 (Ep) の経時変化

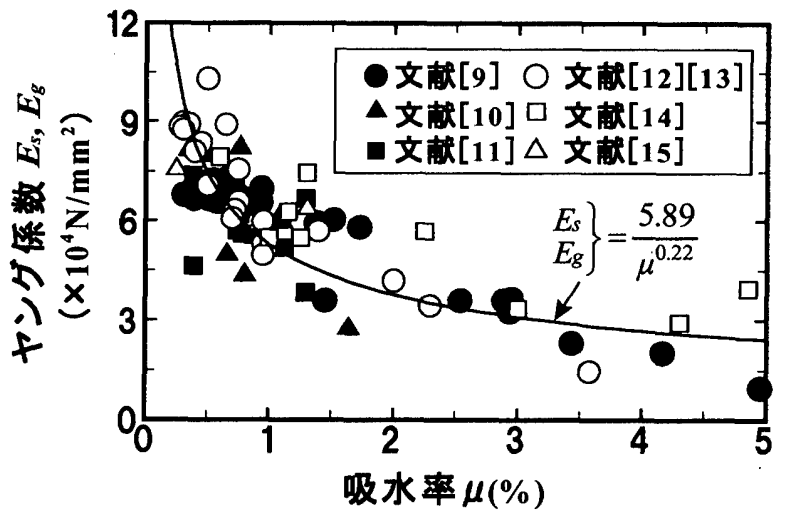

図-6＼cjkstart骨材のヤング係数と吸水率の関係

\section{（1）普通骨材}

骨材のヤング保数は, コンクリートの力学特性に大きく影響を及ぼ しているが, 実際には同じ岩石名のものでも, 生成年代や深さ, 地域, 風化の度合いなどによって性質が様々に異なるため, 骨材のヤング俰 数は曖昧である。そこで, 骨材の何らかの普遍的な特性とヤング係数 を結びつけるデータが必要となってくる。ここでは骨材の吸水率に着 目し, 骨材のヤング係数との関係性について調べた。図-6に既往の研 究より得られた骨材のヤング保数と吸水率の関係を示す。荻野 ${ }^{16)}$ の研 究よれば吸水率とヤング係数との間には有意水淮 $1 \%$ で相関関係があ ると述べている。また, その他の研究者も吸水率とヤング保数の相関 性について認めている。そこで, 図-6の収集データより骨材のヤング 係数は，式(6)に示す実験式で表すこととした。しかしながら，図に 示すように同じ吸水率においてもヤング係数の値が大きく異なって いるものもあり，骨材のヤング係数とどのような特性を結びつけるの が最も妥当かについては，今後も引き続き検討していく必要がある。 


$$
\left.\begin{array}{l}
E_{s} \\
E_{g}
\end{array}\right\}=\frac{5.89}{\mu^{0.22}}
$$

ここに, Es: 細骨材のヤング係数 $\left(\times 10^{4} \mathrm{~N} / \mathrm{mm}^{2}\right)$ $E g:$ 粗骨材のヤング係数 $\left(\times 10^{4} \mathrm{~N} / \mathrm{mm}^{2}\right)$ $\mu:$ 吸水率 $(\%)$

\section{(2) 軽量骨材}

軽量骨材のヤング係数は, 普通骨材のヤング係数と比較すると小さ く，ヤング倸数と吸水率の関係は式(6)では表すことができない。そ こで, 軽量骨材を成型加工せず強度評価を行っている原田ら ${ }^{17}$ の研究 に基づいて軽量骨材の圧壊試験を行い, 球面と平面の接触応力より式 （7）を用いて軽量骨材のヤング係数を求めることとした。軽量コンク リートの練混ぜにおいて骨材のプレウェッチングを行っていないこ とから，圧壊試験で用いた骨材は気乾状態のものを用いた。

$$
\begin{gathered}
E_{g}=\frac{3 \cdot P \cdot E_{1} \cdot\left(1-v_{2}^{2}\right)}{\sqrt{16 \cdot \delta^{3} \cdot r \cdot E_{1}^{2}-9 \cdot P^{2} \cdot\left(1-\dot{v}_{1}^{2}\right)^{2}}} \\
こ こ に, \quad \delta: \text { 変位 }(\mathrm{mm}), P: \text { 荷重 }(\mathrm{N}), \\
r: \text { 骨材半径 }(\mathrm{mm}), E_{1}: \text { 压板の弾性係数 }\left(\mathrm{N} / \mathrm{mm}^{2}\right) \\
v_{1}, v_{2}: \text { 圧板, 骨材のポアソンン比 }
\end{gathered}
$$

式(7)において $E_{1}=2.1 \times 10^{5} \mathrm{~N} / \mathrm{mm}^{2}, \quad v_{1}=v_{2}=0.3$ と仮定し， $\delta$ は測定 変位から圧板自体の変位を除去したものを用いた。圧壊強度は骨材径 による影響を受けることが考えられるため, 骨材径が $15 \mathrm{~mm}$ 程度のも のを採取して行った。圧壊試験は図-7に示すよう載荷板に骨材を挟み $0.5 \mathrm{~mm} / \mathrm{min}$ の速さで載荷した。受圧面で圧壊しているが，いずれの骨 材も中心部で引張破壊を起こしていることが確認できた。表-5にヤン グ係数の計算結果を示す。これより使用した軽量骨材のヤング係数を $1.45 \times 10^{4} \mathrm{~N} / \mathrm{mm}^{2}$ とした。本論文で示した軽量骨材のヤング係数の算出 方法は骨材の成形などを必要とせず，簡便な実験を行うものであり， 他の軽量骨材にも適用できるものと思われる。しかしながら, 主原料 として産業廃萧物を使用した新しい軽量骨材が開発されており,軽量 骨材も普通骨材と同様に普遍的な特性との関係について検討する必 要があるものと思われる。

\section{(3)ヤング係数の算出}

細骨材および粗骨材のヤング係数は式(6)および式(7)を用いるこ とで算出できる。本研究では，コンクリートをセメントペーストと骨. 材(細骨材十粗骨材)の二相材料として取り扱うこととしているため, 骨材のヤング係数Eaは, 細骨材および粗骨材のヤング係数にコンクリ' 一ト中の細骨材および粗骨材の絶対容積比を乗じた值(式 (8) 参照) と した。算出した骨材のヤング係数の一覧表を表-6に示す。

$$
\begin{aligned}
& E_{a}=(s / a) \cdot E_{s}+(1-(s / a)) \cdot E_{g} \\
& \text { ここに, s/a: 細骨材率 }
\end{aligned}
$$

\begin{tabular}{|c|c|c|c|}
\hline No. & \begin{tabular}{|l|} 
直径 \\
$(\mathrm{mm})$ \\
\end{tabular} & $\begin{array}{c}\begin{array}{c}\text { 压罜荷重 } \\
(\mathrm{N})\end{array} \\
\end{array}$ & $\begin{array}{c}\text { ヤング係数 } \\
\left(\times 10^{4} \mathrm{~N} / \mathrm{mm}^{2}\right)\end{array}$ \\
\hline 1 & 15.66 & 1020 & 2.45 \\
\hline 2 & 14.21 & 1046 & 1.28 \\
\hline 3 & 15.13 & 1679 & 1.58 \\
\hline 4 & 15.28 & 1558 & 1.12 \\
\hline 5 & 14.96 & 1592 & 1.05 \\
\hline 6 & 14.52 & 942 & 1.23 \\
\hline \multicolumn{3}{|c|}{ 空常均 } & 1.45 \\
\hline
\end{tabular}

\section{4. 複合則理論を用いたヤング係数の推定}

\section{1 複合則理論の適用}

式(3)とこれに付随する式(4), 式(5), 式(6), 式(7)および式(8)

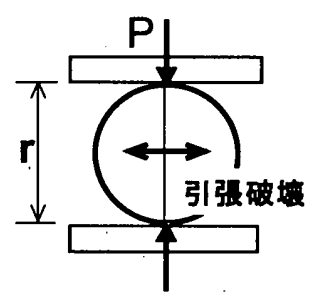

図-7 圧壊試験模式図
表-5，圧壊試験結果一覧

表-6 骨材のヤング係数の算出結果一筧表

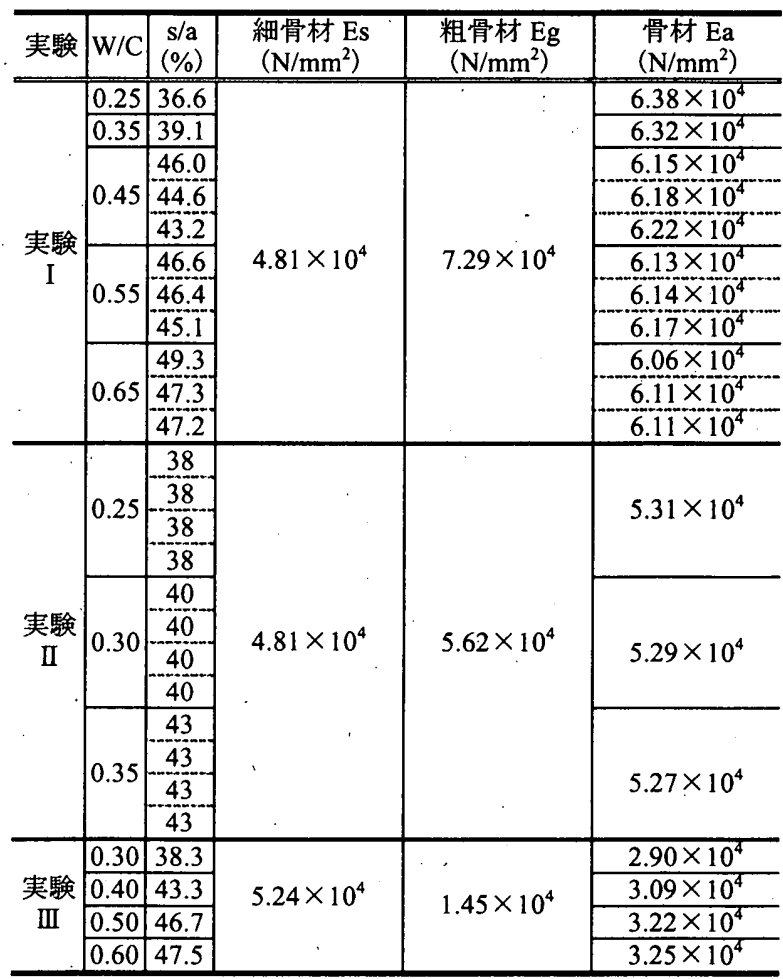

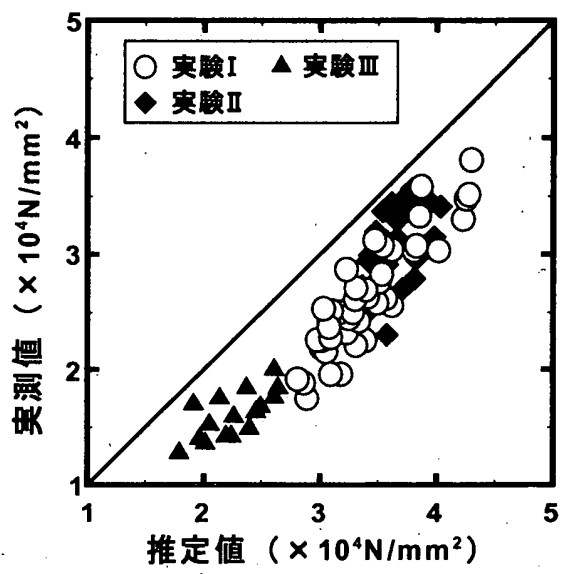

図-8 推定值と実測値の比較

が本論文において提案するコンクリートのヤング係数の推定式であ る。これらの式は, 水セメント比, 骨材の吸水率, 骨材容積比をパラ メータとしており，本実験と同様の一定条件下においては，調合設計 時に得られるデータを用いて, 任意の材跉におけるコシクリートのヤ ング係数を予測できることになる。本提案式を検証するために，2章 で行った実験デー夕を基に，式(4)における補正係数 $k=1$ としてぺー 


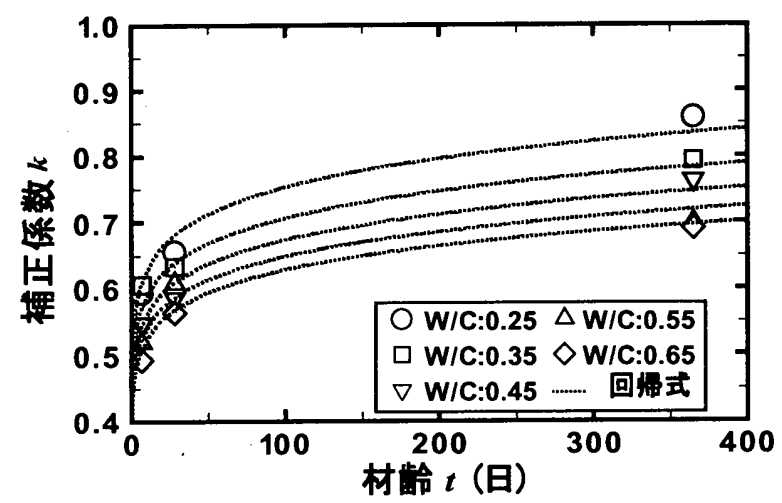

図-9 補正係数 $k$ と水セメント比の関係(実験 I の場合)

ストのヤング係数を，式(6)，式(7)および式(8)より骨材のヤング係 数を推定し，これらの值を式(3)に代入してコンクリートのヤング俰 数の推定を行った。なお，推定値と実測值を比較したものを図-8に示 す。これによると，推定值は実測值より大きい值を与えることが分か る。コンクリートが二相モデルであるという仮定に基づいて得られた 複合理論式は，弹性理論に基づいており，骨材界面に形成される遷移 帯領域の影響を考慮していないため, 実測値より大きい值を与えるこ とが指摘されている ${ }^{18)}$ 。そこで，骨材界面に生じるマイクロクラック および骨材界面に形成される遷移帯領域の影響を考慮するために導 入した式(4)の補正係数 $k$ は, 実測值から逆算して求めることとした。 求めた $k$ の值と水セメント比の関係の一例を図-9に示す。これより, 水セメント比が小さいほどkの值が大きくなることが分かる。内川ら 19)の研究によれば水セメント比が小さいほど形成される遷移帯領域 の厚さは小さくなると言われている。そこで，水セメント比が小さい ほどまた, 材齢が進行するほどヤング係数に及ぼす遷移帯領域の影響 は小さくなるものと仮定し, 補正係数 $k$ を水セメント比と材龄の関数 である式(9)で表すこととした。

$$
\begin{aligned}
& \text { 普通・高強度コンクリートの場合 } \\
& \quad k=\alpha \cdot t^{0.08} \quad \alpha=0.4 \cdot x^{-0.19} \\
& \text { 軽量コンクリートの場合 } \\
& \quad k=0.37 \cdot t^{0.12} \\
& \text { ここに, } t: \text { 材齢 }(\text { 日) }, \quad x: \text { 水セメント比 }
\end{aligned}
$$

図-9の曲線は式(9)より得られたものである。なお，軽量骨材を用 いた場合については，本実験では水セメント比による影響が見られな かったため，材齢のみをパラメータとする関数とした。僄移帯領域は 骨材表面形状の影響を受忛ることが指摘されており，表面形状と遷移 帯領域の関係や遷移帯領域を考慮した補正係数の導入方法について も引き続き検討していく必要があるものと思われる。

式(9)を用いて算出した補正係数を式(8)に代入して推定した結果 と実測値を比較したものを図-10に示す。図中の実線は実測值との誤 差が $0 \%$, 点線は誤差士 $10 \%$ を示している。これによると,若干ばらつ きはあるが，推定值は実測值をよく表しているものと思われる。

遷移帯領域を加味した補正係数の導入については課題を残してい るが, 本実験の範囲内においては本提案式を用いることによって広範 囲のコンクリートのヤング係数の推定が可能であると考えられる。

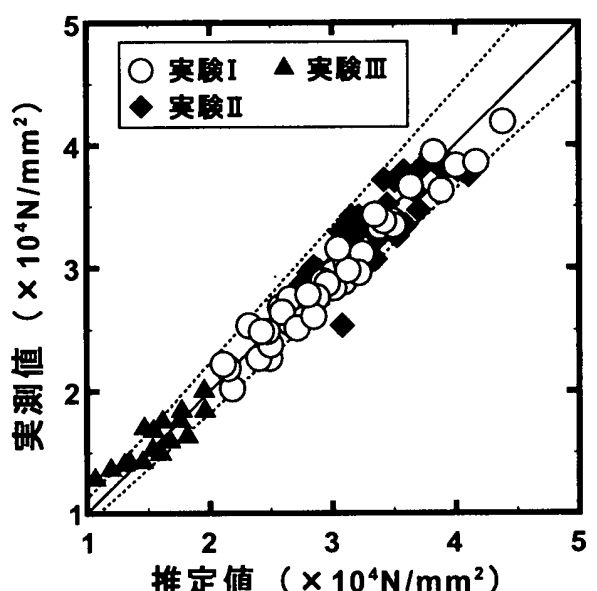

図-10 推定値と実測値の比較(補正係数考慮)

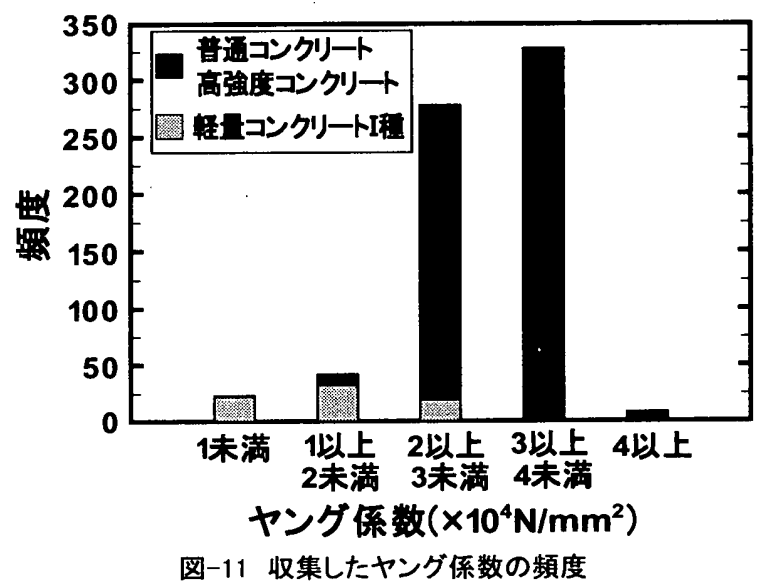

4.2 提案式の適用性の検証

4.1 節で提案した複合則理論を用いたヤング係数推定式の汎用性を 探るため, 1982〜2002 年において日本建築学会大会学術講演梗概集, コンクリートエ学年次論文報告集およびセメント技術年報(セメン ト・コンクリート論文集)などに公表されたコンクリートの圧縮強度 とヤング係数との関係に関する約 670 件の実験データを収集し, 推定 式の適用性の検証を行った。本論文では，養生条件およびセメントの 種類を一定とした条件下におけるヤング係数の推定式を提案するこ とを目的としているため, 実験データの収集条件を，(1)普通ポルト ランドセメントのみを使用したもの，（2）養生条件を封かん養生およ び水中養生としたもの，(3) 軽量骨材は，人工軽量骨材を使用したもの とした。収集したデー夕は，コンクリートの圧縮強度，ヤング係数，圧 縮強度試験時の単位容積質量に加えて, コンクリートの使用材料の種 類・物性および調合，フレッシュコンクリートの物性である。

図-11 に収集したデータについて示す。普通および高強度コンクリ ートのデータ数は 606, 軽量コンクリートI 種のデータ数は 53 であ る。普通および高強度コンクリートでは $3 \times 10^{4} \mathrm{~N} / \mathrm{mm}^{2}$ 以上 $4 \times$ $10^{4} \mathrm{~N} / \mathrm{mm}^{2}$ 未満のデータが最も多く, 軽量コンクリートI 種では $1 \times$ $10^{4} \mathrm{~N} / \mathrm{mm}^{2}$ 以上 $2 \times 10^{4} \mathrm{~N} / \mathrm{mm}^{2}$ 未満のデータが最も多い。このようなデ 一夕を基に，表-7 に示すような㴼強度および単位容積質量をパラ メータとする既往のヤング係数推定式との比較検討を行った。これら の推定式の適用にあたって軽量骨材のヤング係数においては, 圧壊試 
験が実施できないため, 全て本実験で得られた実験値である $1.45 \times$ $10^{4} \mathrm{~N} / \mathrm{mm}^{2}$ を用いた。AIJ 式における $F_{c}$ (設計基隻強度)には，圧縮強 度の㬰測值を用いた。 $\mathrm{ACI}$ 式においては $f c^{\prime} \leqq 21 \mathrm{~N} / \mathrm{mm}^{2}$ では上段の式 を用いた。

各推定式から求めたヤング俰数の計算値と実測值の差，すなわち 残差と水セメント比の関係を図-12 に示す。なお，図中には ACI 式お よび CEB 式の適用範囲外のデータについてもプロットしている。こ れらの結果より, AIJ 式(図-12b)）では, 軽量コンクリートの一部の データでは值を過大評価する傾向にある。また，普通骨材を使用した コンクリートでは水セメント比の高い領域で若干過小評価する傾向 が見られる。 ACI 式 (図-12 c)) では, 軽量骨材を用いた場合に過大 評価する傾向が見られる。また水セメント比の増加とともに過小評価 する傾向を示している。CEB 式 (図-12d)) では全体的に過大評価す る傾向が見られる。提案式（図-12a)）では水セメント比の增加とと

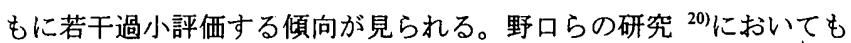
同様な検討がなされており，ACI 式および CEB 式において同様な傾 向が報告されている。

表-8に求めた残差の平均値, 分散を示す。平均值は 0 に近いほど, 推定結果の精度が良く, 分散は小さい值になるほどそのばらつきが小 さいことを示す。これによると，残差の平均值は普通・高強度コンク リートの場合は提案式, 軽量コンクリート I 種は AIJ 式が最も0に近 い值を示し, 分散は, 普通・高強度コンクリートの場合は ACI 式, 軽量コンクリート I 種は CEB 式が最も小さい値を示している。

これらのことより，一定の条件下においてではあるが，本提案式 は，骨材の種類によらず，普通強度から高強度までの広範囲の強度レ ベルのコンクリートや骨材の種類が異なるコンクリートのヤング係 数を比較的精度良く推定出来ると考えられる。
表-7 既往のヤング係数推定式

\begin{tabular}{|c|c|}
\hline 略称 & ヤング係数の推定式および設計値 \\
\hline $\begin{array}{l}\text { 日本建築 } \\
\text { 学会式 }{ }^{1)} \\
\text { (AIJ 式) }\end{array}$ & $\begin{aligned} & E_{c}= 33.5 \times k 1 \times k 2 \times\left(\frac{\gamma}{2.4}\right)^{2} \times\left(\frac{F_{c}}{60}\right)^{\frac{1}{3}} \\
& E_{c}: \text { コンクリートのヤング係数 }\left(\mathrm{kN} / \mathrm{mm}^{2}\right) \\
& F_{c}: \text { コンクリートの設計基準強度 }\left(\mathrm{N} / \mathrm{mm}^{2}\right) \\
& \gamma: \text { コンクリート気乾単位容積質量 }\left(\mathrm{t} / \mathrm{m}^{3}\right) \\
& k_{1}: \text { 骨材の種類によって決まる定数 } \\
& k_{2}: \text { 混和材の種類によって決まる定数 }\end{aligned}$ \\
\hline $\mathrm{ACI}^{21), 22)}$ & $\begin{aligned} E_{c}= & W_{c}^{1.5} \times 1350 \times \sqrt{f_{c}^{\prime}} \ldots \ldots \ldots \ldots \ldots \ldots \ldots . . . f c^{\prime}<41 \mathrm{~N} / \mathrm{mm}^{2} \\
E_{c}= & 3320 \times \sqrt{f_{c^{\prime}}}+6900 \cdots 21 \mathrm{~N} / \mathrm{mm}^{2}<f c^{\prime}<83 \mathrm{~N} / \mathrm{mm}^{2} \\
& E_{c}: \text { コンクリートのヤング係数 }\left(\mathrm{N} / \mathrm{mm}^{2}\right) \\
& W c: \text { 単位容積質量 }\left(\mathrm{kg} / \mathrm{m}^{3}\right) \\
& f_{c^{\prime}}: \text { 標準円柱供試体の } 28 \text { 日圧縮強度 }\left(\mathrm{N} / \mathrm{mm}^{2}\right)\end{aligned}$ \\
\hline CEB-FIP ${ }^{23)}$ & 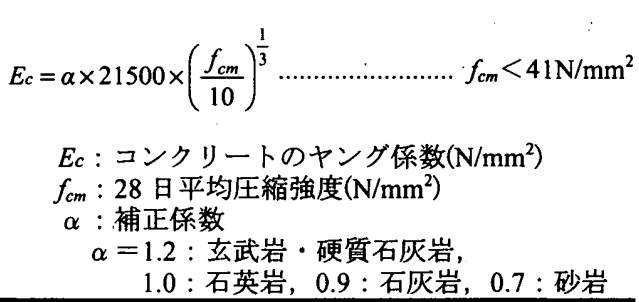 \\
\hline
\end{tabular}

表-8 残差の平均·分散

\begin{tabular}{c|c|c|c|c|c}
\hline \multicolumn{2}{c|}{} & 提案式 & AIJ 式 & ACI 式 & CEB 式 \\
\hline \multirow{2}{*}{ 平均値普通・高強度 } & -0.085 & -0.155 & -0.188 & 0.385 \\
\cline { 2 - 6 } & 軽量 I 種 & -0.081 & 0.009 & 0.370 & 1.345 \\
\hline \multirow{2}{*}{ 分散 } & 普通・高強度 & 0.165 & 0.194 & 0.121 & 0.194 \\
\cline { 2 - 6 } & 軽量 I 種 & 0.039 & 0.243 & 0.231 & 0.026 \\
\hline
\end{tabular}

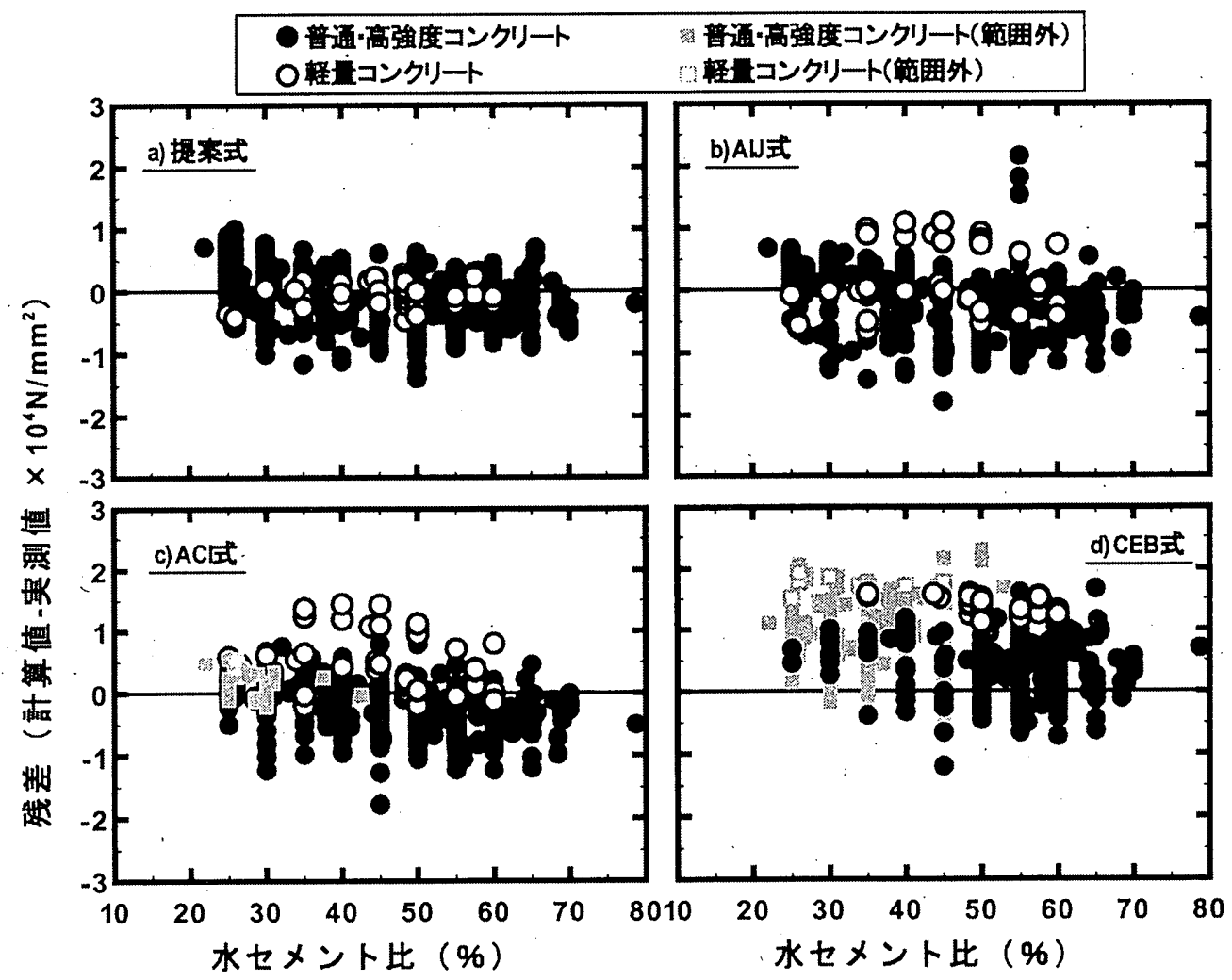

图-12 水セメント比と各推定値の残差の関係 


\section{5. まとめ}

本研究では, 複合則理論式を用いたコンクリートのヤング係数の推 定式について提案し，その汎用性について検討を行った。養生条件お よびセメントの種類を一定とした条件下における本研究の範囲内で 得られた知見は以下の通りである。

(1) コンクリートの構成材料の1つである母材セメントペーストのヤ ング係数は, 水セメント比および材龄をパラメータとする式(5) で算出できる。

(2) コンクリートの構成材料の1つである骨材のヤング係数は, 普通骨 材の場合は吸水率をパラメータとした式(6)で, 軽量骨材の場合は 圧壊試験の結果による式(7)で算出できる。

（3）コンクリートのヤング係数は, Hashin-Hansenの複合則理論式を基 に，僄移帯領域などを考虑した係数を用いて修正した下式を用い ることによって推定できる。

$$
\begin{gathered}
\frac{E_{c}}{E_{p}}=\frac{\left(1-V_{a}\right) \cdot E_{p}+\left(1+V_{a}\right) \cdot E_{a}}{\left(1+V_{a}\right) \cdot E_{p}+\left(1-V_{a}\right) \cdot E_{a}} \\
\text { こに,} \quad E_{p}(x, t)=k \cdot \bar{E}_{p}(x, t) \\
\bar{E}_{p}(x, t)=\frac{A \cdot t}{1+t} \quad A=0.036+0.66 \cdot \frac{1}{x} \\
E_{a}=s / a \cdot E_{s}+(1-s / a) \cdot E_{g}
\end{gathered}
$$

\begin{tabular}{c|c|c}
\hline & 普通骨材 & 軽量骨材* \\
\hline$k$ & $\begin{array}{l}k=\alpha \cdot t^{0.08} \\
\alpha=0.4 \cdot x^{-0.19}\end{array}$ & $k=0.37 \cdot t^{0.12}$ \\
\hline$E_{s}$ & $E_{s}=\frac{5.89}{\mu^{0.22}}$ & - \\
\hline$E g$ & $E_{g}=\frac{5.89}{\mu^{0.22}}$ & $1.45 \times 10^{4}$ \\
\hline
\end{tabular}

*適応できる軽量骨材は人工軽量骨材のみ

$$
\begin{aligned}
& E_{c}: \text { コンクリートのヤング係数 }\left(\times 10^{4} \mathrm{~N} / \mathrm{mm}^{2}\right) \\
& E_{p}: \text { セメントペーストのヤング係数 }\left(\times 10^{4} \mathrm{~N} / \mathrm{mm}^{2}\right) \\
& E_{a}: \text { 骨材のヤング係数 }\left(\times 10^{4} \mathrm{~N} / \mathrm{mm}^{2}\right) \\
& V_{a}: \text { 骨材容積比 }\left(\mathrm{m}^{3} / \mathrm{m}^{3}\right) \\
& E_{s}: \text { 細骨材のヤング係数 }\left(\times 10^{4} \mathrm{~N} / \mathrm{mm}^{2}\right) \\
& E_{g}: \text { 粗骨材のヤング係数 }\left(\times 10^{4} \mathrm{~N} / \mathrm{mm}^{2}\right) \\
& x: \text { 水セメント比, } t: \text { 材齢 }(\text { 日 }), \mu: \text { 吸水率 }(\%)
\end{aligned}
$$

（4）本提案式は水セメント比, 単位水量 (骨材量), 細骨材率, 使用骨 材の吸水率をパラメータとしており，コンクリートの調合設計時 に必要な所定の材躴のヤング係数を推定することが可能となるも のと思われる。

\section{謝辞}

本研究の実施にあたり，株式会社ポゾリス物産 : 伊藤忠氏，株式会 社さとうベネック：上田賢司氏，大分大学文部技官 : 遠矢義秋氏，大 分大学修論生 : 上原裳氏 (1997年度), 長谷川浩延氏 (1999年度), 川村 祐史氏 (2001年度)ならびに大分大学福祉環境工学科建築コース材料 施工研究室の皆様に多大なご協力を賜りました。ここに記して厚く謝 意を表します。

\section{参考文献}

1）日本建築学会：鉄筋コンクリート構造計算基準・同解説 - 許容応力度設計 法一, 1999

2）川上英男：コンクリートの弾性係数と近似複合理論，コンクリートエ学 年次論文報告集，Vol.17，No.1，pp.497-500，1995.6

3）清原千鶴ほか6名: コンクリートの力学特性に関する基礎的研究 (その1，その2), 日本建築学会九州支部研究発表会第37号·1，pp.85-92，1999.3

4）長谷川浩延ほか 6 名：複合則理論によるコンクリートの各種力学特性に関す る基礎的研究（その1.セメントペーストおよびコンクリートの圧穛強度とヤ ング係数の実験結果), 日本建築学会大会学術講演梗概集, A-1 分冊, pp.685-686, 1999.9

5）長谷川浩延ほか6名：高強度コンクリートの力学特性に関する研究(その2.高 强度コンクリートのヤング係数・乾燥収縮ひずみ)，日本建築学会学術講演 梗概集，A-1分冊，pp.815-816，1998.9

6）川村祐史ほか6名：人工軽量骨材を用いたコンクリートのヤング俰数と乾 燥収樎ひずみ(その1.圧縮強度，ヤング係数および乾燥収維)，日本建築学会 大会学術請演梗概集，A-1分冊，pp.531-532，2000.9

7) B.Paul : Prediction of elastic constants of multiphase materials, Trans. AIME, Vol.218, 1960.

8) T.C.Hansen : Influence of Aggregate and Voids on Modulus of Elasticity of Concrete, Cement Mortar, and Cement Paste, Journal of ACl, pp.193-216 1965.2

9）立松和彦：コンクリートの細孔分布と耐久性に関する研究，浅沼組技術研 究所報（別冊），pp.17-26，2001.5

10）山口梅太郎, 西松裕一: 岩石力学入門, 財団法人東京大学出版会, pp.123-168, 1991.8

11）鶴田浩章：高強度コンクリートの力学的性質に及ほす粗骨材品翼の影㜅に 関する基磷的研究，九州大学博士論文，2001.3

12）萩野正二，渡辺久夫：日本釷業会講演要旨，1971

13）获野正二，渡辺久夫：日本鉱業会講演要旨，1970

14）馬場明生：建築材料の乾燥収繣機構とその応用に関する研究，東京大学博 士論文, 1975.6

15) T.J. Hirsh : Modulus of Elasticity of Concrete Affected by Elastic Modulus of Cement Paste Matrix and Aggregate, J. of ACI, vol.59, No.3, 1962.3

16）萩野正二，渡辺久夫：日本鉱業会講演要旨，1972

17）原田至克ほか 3 名: 人工軽量骨材の強度評価方法，太平洋セメント研究報告 第 136 号, pp.49-58， 1999

18）川上英男:コンクリートの弾性係数に及ぼす骨材と境界層の影響，コンクリート 工学年次論文集，Vol.22， No.2，pp.529-534，2000.6

19) Uchikawa Hiroshi : Similarities and Discrepancies of Hardened Cement Paste, Mortar and Concrete from Standpoints of Composition and Structure, Engineering Foundation Conference, Advances in the Production and Utilization of Cement Based Materials, Vol.1, pp.271-310, 1988.

20）野口貴文，友澤史紀 : 高強度コンクリートの瓦縮强度とヤング保数との関 倸，日本建築学会粠造系論文集，No.474，pp.1-10，1995.8

21) $\mathrm{ACl}$ Committee Report, Building Code Requirements for Reinforced Concrete and Commentary, ACI Committee 318, 1981

22) $\mathrm{ACl}$ Committee Report, State-of the Art Report on High-Strength Concrete, $\mathrm{ACl}$ Committee 363,1995

23) CEB-FIP Model code 1990, Partl. Design Input Data, 2.Material Properties, 1990 （2003年 7 月10日原稿受理，2003年11月21日採用決定） 